\title{
Desentralisasi Asimetris dalam Konteks Negara Kesatuan
}

\author{
Sri Nur Hari Susanto \\ Fakultas Hukum, Universitas Diponegoro \\ Co: nurhari60@yahoo.co.id
}

\begin{abstract}
The correlation between decentralization and deconcentration on the concept of a unitary state and a federal state is not dichotomous, but rather forms a matrix or continuum relationship. Within the continuum, it is possible to shift the pendulum swing both centripetally (concentrating or cone in higher power) or centrifugal (spreading or dispersing into the power of smaller government units). In the practice of relations between the center and the regions in various countries, the pendulum swing of unitarism (unity) and federalism move in opposite directions.
\end{abstract}

Keywords: Decentralization, Asymmetric, Republic of Indonesia

\begin{abstract}
Abstrak
Korelasi hubungan desentralisasi dan dekonsentrasi antara konsep negara kesatuan dengan negara federal tidak bersifat dikhotomis yang saling berlawanan, melainkan membentuk sebuah hubungan matriks atau kontinum. Dalam rentang garis kontinum tadi, sangat dimungkinkan terjadinya pergeseran pendulum baik yang bersifat sentripetal (memusat atau mengerucut dalam kekuasaan yang lebih tinggi) maupun yang sentrifugal (menyebar atau pemencaran kedalam kekuasaan unit pemerintahan yang lebih kecil). Dalam praktik hubungan antara pusat dan daerah di berbagai negara, pendulum unitarisme (kesatuan) dan federalisme saling bergerak ke arah yang berlawanan.
\end{abstract}

Kata Kunci: Desentralisasi, Asimetris, Negara Kesatuan Republik Indonesia.

\section{A. Pendahuluan}

Memperbincangkan hubungan pusat dan daerah dalam bingkai negara kesatuan cukup menarik untuk dikaji. Masalah yang timbul dalam prakteknya adalah mengenai tarik menarik kepentingan yang tidak dapat dihindarkan. Dalam konsep negara kesatuan, upaya pemerintah pusat untuk selalu memegang kendali atas berbagai urusan pemerintahan sangat jelas, sebab kelaziman negara yang berbentuk kesatuan, maka sebagai pemegang otoritas pemerintahan adalah pusat. Kewenangan yang diberikan oleh pusat kepada daerah sangat terbatas.

Dalam konteks di atas, pemerintah pusat atau nasional memposisikan pada kedudukan tertinggi, dan memiliki kekuasaan penuh dalam pemerintahan sehari-hari, dan tidak ada bidang kegiatan pemerintah yang diserahkan konstitusi kepada satuan-satuan pemerintahan 
yang lebih kecil (dalam hal ini daerah atau provinsi, kabupaten/kota). Pemerintah pusat (nasional) bisa melimpahkan banyak tugas (melimpahkan wewenang) kepada kota-kota, kabupaten-kabupaten, atau satuan-satuan pemerintahan lokal. Namun, pelimpahan wewenang ini hanya diatur oleh undang-undang yang dibuat parlemen pusat (di Indonesia DPR-RI), bukan diatur di dalam konstitusi (di Indonesia UUD 1945), dan pelimpahan wewenang tersebut bisa saja ditarik sewaktu-waktu.

C.F. Strong menyatakan bahwa ciri mutlak yang melekat pada negara kesatuan ialah: pertama, adanya supremasi dari dewan perwakilan rakyat pusat, dan kedua, tidak adanya badan-badan lain yang berdaulat. ${ }^{1}$ Kekuasaan pemerintah dalam suatu negara yang berbentuk kesatuan seperti itu dapat diselenggarakan dengan cara terhimpun/ditumpuk (gathered) secara sentralisasi (centralized $)^{2}$, sehingga segala urusan dalam negara terletak di tangan pemerintah pusat (central government), dan semua kewenangan pemerintah dilakukan oleh satu pusat pemerintahan (single centralized government), atau oleh pusat bersama-sama dengan organnya yang berada / dipencarkan di daerah-daerah ${ }^{3}$. Pemencaran organ-organ yang menjalankan kewenangan pemerintah pusat di daerah-daerah seperti itu, menurut Bagir Manan dikenal sebagai dekonsentrasi (centralisatie met de deconcentratie), di mana semua kewenangan menyelenggarakan pemerintahan daerah, termasuk kewenangan organ-organ dalam membentuk peraturan perundang-undangan didasarkan atau sangat tergantung pada pemerin-tah (pusat) ${ }^{4}$.

Pemerintah pusat juga mempunyai wewenang untuk menyerahkan sebagian kekuasaannya kepada daerah berdasarkan hak otonomi. Ini dikenal sebagai desentralisasi, namun kekuasaan tertinggi tetap berada di tangan pemerintah pusat. Kajian terhadap kekuasaan pemerintahan, maka dalam pemerintahan yang konstitu-sional dan demokrasi, pembagian kekuasaan merupakan dasar bagi pemerintahan yang beradab. Pembagian kekuasaan dimaksud dapat merupakan pembagian kekuasaan yang pokok (capital division of powers) antara legislatif, eksekutif dan yudikatif dan pembagian kekuasaan atas dasar wilayah (areal division of powers). Pembagian kekuasaan yang terakhir menyangkut baik desentralisasi khususnya maupun dekonsentrasi.

\footnotetext{
${ }^{1}$ Lihat dalam Miriam Budiharjo, Dasar-dasar Ilmu Politik, (Jakarta: Gramedia, 2000), hlm. 140.

${ }^{2}$ Abu Daud Busroh, Ilmu Negara, (Jakarta: Bumi Aksara, 2001), hlm. 145-146.

${ }^{3}$ Martin H. Hutabarat (eds), Hukum dan Politk Indonesia: Tinjauan Analitis Dekrit Presiden Dan Otonomi Daerah, (Jakarta: Pustaka Sinar Harapan, 1996), hlm. 140.

${ }^{4}$ F. Isjwara, Pengantar Ilmu Politik, (Bandung: Bina Cipta, 1980), hlm. 212-213.
} 
Pada masa kini frekuensi pembahasan mengenai masalah tersebut semakin meningkat. Pembahasan desentralisasi dan dekonsentrasi memperoleh tempat terhormat dalam forum internasional dan sejumlah pemikiran telah tumbuh dan berkembang di kalangan para ahli. Desentralisasi pada umumnya dipandang sebagai instrumen guna pencapaian nilai-nilai dalam masyarakat.

Sebagai suatu sistim, desentralisasi saling berinteraksi dengan lingkungannya dimana desentralisai beroperasi. Lingkungan tersebut dapat berupa faktor politik, sosiobudaya, ekonomi, historis dan geografis. Oleh karena itu, apabila kita ingin memahami desentralisasi dengan baik diperlukan pendekatan ekologis. Dengan pendekatan itu memungkinkan penganalisaan yang lebih dinamis dari pada pendekatan dari satu arah (uni directional approach). Kedudukan "istimewa" bagi Daerah istimewa Aceh dan Yogyakarta misalnya, dan mengapa keistimewaan Aceh berbeda dengan Yogyakarta tidak dapat diungkap dengan ketentuan-ketentuan hukum semata, tetapi diperlukan penglihatan dari faklor-faktor non hukum.

Menyadari desentralisasi sebagai suatu sistem dan pada akhirnya hanyalah merupakan sub-sistem dari sistem sosial secara keseluruhan, maka dapat dimengerti apabila beroperasinya desentralisasi dalam masyarakat juga bervariasi dari tempat dan waktu dalam suatu negara dan diantara negara-negara. Sebagai suatu instrumen guna pencapaian nilai-nilai dalam masyarakat, desentralisasi tidak saja dijalankan oleh pemerintah negara-negara merdeka, tetapi juga pemerintahan kolonial. Adakalanya pemerintahan kolonial, sambil melakukan pengawasan di seluruh wilayah dengan alat-alat komunikasi yang sederhana, membangun sistem desentralisasi yang didasarkan pada struktur masyarakat tradisional.

Secara umum, bentuk negara-negara modern di dunia dewasa ini dapat diklasifikasikan kedalam 2 (dua) bentuk yakni negara federal (federal states, bondstaat, bundesstaat) dan negara kesatuan (unitary states, eenheidstaat) ${ }^{5}$. Dilihat dari jumlah dan persebarannya, negara yang menganut kedua sistem ini nampaknya relatif berimbang. Hal ini menunjukkan bahwa paham yang satu tidak cenderung dominan dibanding paham yang lain. Namun

\footnotetext{
${ }^{5}$ Elazar menyebutkan bahwa kategorisasi negara modern menjadi dua bentuk yakni kesatuan dan republik, dapat menimbulkan kekaburan tentang 3 (tiga) model asli dari sistem kepolitikan, yakni hierarchic, organic, dan covenantal. Karakteristik dua model pertama lebih condong pada negara kesatuan, sedangkan model ketiga lebih dekat dengan konsep negara federal. Elazar, Daniel J., "Contrasting Unitary and Federal Systems", dalam International Political Science Review / Revue internationale de science politique, Vol. 18, No. 3, Sage Publications, 1997, hlm. 237.
} 
jumlah negara kesatuan secara empiris lebih banyak daripada negara federal. Berdasar uraian latar belakang di muka, maka isu sentral yang menjadi pokok bahasan dalam tulisan ini adalah bagaimana konsep ideal desentralisasi dalam konteks Negara Kesatuan.

\section{B. Hasil Penelitian dan Pembahasan}

\section{Negara Kesatuan dan Negara Federal.}

Mengutip pendapat Shah dan Thompson, Hoessein menyebutkan bahwa jumlah negara mengalami kenaikan dari 140 di tahun 1975 menjadi 192 di tahun 2001. Pada tahun yang sama 24 dari 192 negara berbentuk federal, sedang sisanya adalah negara kesatuan (168). Di antara jumlah Negara kesatuan tersebut (168) terdapat 20 negara yang menganut desentralisasi dengan ciri-ciri federal, termasuk Indonesia ${ }^{6}$.

Makna negara kesatuan sendiri relatif konsensual, dalam arti tidak mengundang perde-batan sebagaimana terjadi dalam pendefinisian desentralisasi dan dekonsentrasi. Dalam hal ini, negara kesatuan dimaknai sebagai negara yang diatur secara konstitusional sebagai satu unit yang mandiri, dengan satu lembaga legislator yang diciptakan secara konstitusional pula. Kekuasaan politis dari negara kesatuan dapat ditransfer kepada pemerintahan yang lebih rendah namun pemerintah (pusat) tetap memegang hak dasar untuk mencabut kembali kewenangan yang telah ditransfer tersebut. Pemerintah dapat menambah atau mengurangi kewenangan tanpa persetujuan dari lembaga bersangkutan. Demikian pula, pemerintahan daerah dapat dibentuk atau

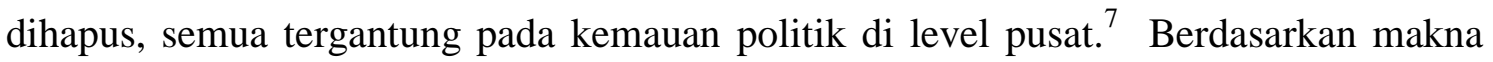
tersebut nampak adanya keterkaitan antara bentuk negara kesatuan dengan desentralisasi. Disini, desentralisasi dapat diaplikasikan untuk unit pemerintahan yang lebih rendah asal didudukkan dalam kerangka negara kesatuan. Pada saat yang sama, desentralisasi tersebut dapat diikuti pula dengan dekonsentrasi, devolusi, ataupun delegasi.

\footnotetext{
${ }^{6}$ Meskipun kedua konsep tersebut bisa dibedakan, namun ada persamaan diantara keduanya, yakni keinginan untuk mempertemukan berbagai perbedaan dan kepentingan dalam sebuah bingkai politik bernama negara. Itulah sebabnya, baik negara federal maupun negara kesatuan sering digunakan jargon unity in diversity atau diversity in unity secara bergantian. Selain jargon tersebut, negara kesatuan yang cenderung mendorong desentralisasi dapat pula mengembangkan jargon unity without uniformity; sedangkan negara federal yang tetap memperkuat peran pemerintah pusat lebih tepat menggunakan jargon diversity without fragmentation. Tentang jargon-jargon ini, lihat http://bahai-library.com/theses/unity.diversity.html

7 Tentang makna negara kesatuan ini dapat diperoleh di berbagai sumber, antara lain: http://www.spiritus temporis.com/unitary-state/ ; $\quad$ http://www.economicexpert.com/a/Unitary:state.htm $\quad ; \quad$ dan http://en.wikipedia.org/wiki/Unitary_state.
} 
Pemahaman yang serupa dikemukakan oleh Miriam Budiardjo. Ia memahami negara kesatuan dan negara federal dari susunannya, dan menyatakan bahwa negara kesatuan ialah negara yang bersusun tunggal, baik dilihat dari segi penduduknya, wilayahnya, maupun pemerintahan dan kekuasaannya. Dalam menjalankan pemerintahan pada negara kesatuan, dapat digunakan sistem sentralisasi atau sistem desentralisasi ${ }^{8}$.

Sebagai implikasi logis dari berlakunya kerangka kebijakan desentralisasi yang baru, kewenangan dan urusan pemerintah daerah (khususnya kabupaten/kota) semakin luas sedangkan kewenangan dan urusan unsur pemerintah pusat semakin mengecil. Meskipun demikian, demi mempertahankan eksistensi, integritas dan "hak kedaulatan" suatu negara bangsa (nation-state), maka pemerintah pusat masih memiliki hak-hak tertentu di daerah, atau dapat melakukan intervensi dalam bentuk supervisi, pembinaan, pengawasan, dan penilaian kinerja otonomi di daerah. Hak" intervensi" Pusat atas Daerah ini dapat dijalankan secara langsung oleh instansi tingkat Pusat (departemen/ LPND), maupun secara tidak langsung melalui aparatnya di daerah.

Secara historis, UU No. 5 Tahun 1974 dan UU tentang pemerintahan daerah pada masa sebelumnya, maka alat kelengkapan Pusat di Daerah dijalankan oleh instansi vertikal yang dibentuk sebagai kepanjangan tangan instansi pemerintah di tingkat Pusat. Sedangkan menurut UU No. 22 Tahun 1999, UU No. 32 Tahun 2004 dan UU No.23 Tahun 2014, perangkat / wakil pemerintah Pusat di daerah adalah Gubernur, disamping instansi vertikal yang khusus menjalankan urusan-urusan absolut pemerintah Pusat. Ini berarti pula bahwa provinsi dalam koridor otonomi daerah memiliki 2 (dua) kedudukan, yakni sebagai wakil pemerintah (aparat dekonsentrasi), namun pada saat yang bersamaan juga sebagai pelaksana otonomi daerah itu sendiri (aparat desentralisasi); sedangkan pada kabupaten/kota tidak lagi melekat fungsi dekonsentrasi.

Mengingat tugas desentralisasi provinsi semakin mengecil, maka fungsi-fungsi koordinasi, pembinaan, dan pengawasan (implikasi tugas dekonsentrasi) harus diperkuat. Hal ini dimaksudkan untuk menjamin agar roda otonomi daerah yang

\footnotetext{
${ }^{8}$ Meskipun prinsip sentralisasi dan desentralisasi memiliki probabilitas yang sama untuk digunakan di negara kesatuan, namun dalam realitanya, karena dorongan demokratisasi yang menuntut pemerintah untuk memberikan kesempatan yang lebih besar kepada publik untuk berpartisipasi dalam pengambilan keputusan, maka banyak negara kesatuan yang kemudian meningkatkan derajat desentralisasi dengan memberikan kewenangan kepada unit pemerintahan lebih rendah. Miriam Budiardjo,Ibid.
} 
bergulir di tingkat kabupaten/kota tidak salah arah atau menimbulkan ekses-ekses yang tidak diinginkan. Dengan kata lain, fungsi dekonsentrasi provinsi menjadi faktor kunci terhadap sukses atau gagalnya implementasi desentralisasi politik yang seluas-luasnya (devolution).

Dalam rangka mencapai keseimbangan sekaligus mengontrol dampak negatif yang mungkin muncul dari pelaksanaan desentralisasi tersebut, maka logis bila pemerintah pusat dalam negara kesatuan masih memainkan peran dalam siklus kebijakan pembangunan di daerah melalui implementasi fungsi dekonsentrasi. Dengan kata lain, dekonsentrasi dapat dipandang sebagai sebuah komponen yang terintegrasi dengan desentralisasi. Hal ini bertujuan agar daerah yang menyelenggarakan fungsi desentralisasi tidak menjadi semakin selfish atau memiliki ego yang berlebihan dalam memikirkan daerahnya sendiri. Dengan penguatan dekonsentrasi, kebijakan pembangunan sebuah daerah dapat selalu ditempatkan dalam konteks pembangunan yang lebih luas dan strategis (embedding local policy into broader context of national development and interest). Di sinilah manfaat dekonsentrasi sebagai penyeimbang arus desentralisasi yang begitu deras. Sementara di negara federal, keseimbangan antara pemerintah pusat (federal) dengan pemerintah negara bagian juga menjadi issu yang penting. Sebagian besar menggunakan instrumen desentralisasi untuk mencapainya, namun beberapa negara lain seperti pemerintah Malaysia, lebih suka menerapkan dekonsentrasi dalam mengatur hubungan dengan kerajaan atau negara bagian di wilayahnya ${ }^{9}$.

Secara sederhana dapat diamati bahwa pada umumnya tidak ada korelasi langsung antara bentuk negara dengan derajat desentralisasi. Pada bagian dibawah akan diuraikan lebih jauh tentang karakteristik negara kesatuan dan federal, serta konsep otonomi yang dapat diterapkan pada kedua bentuk negara tersebut. Dengan merangkum berbagai sumber, Hoessein (tanpa tahun) memberikan definisi yang lengkap tentang negara kesatuan sebagai berikut :

"Negara Kesatuan adalah negara tunggal (unitaris); diorganisasikan di bawah sebuah pemerintah pusat (Strong 1951), seluruh kekuasaan pemerintahan konstitusional

${ }^{9}$ Robertson Work, Overview of Decentralization Worldwide: A Stepping Stone to Improved Governance and Human Development, UNDP : 2nd International Conference on Decentralization Federalism: The Future of Decentralizing States ?, 2002, hlm. 11. 
terpusat di tingkat nasional (Baradat 1979); dan the habitual exercise of supreme legislative authority by one central power (Dicey 1950). Pemerintah sub nasional tak memiliki pouvoir constituant (Kranenburg 1955). Pemerintah sub nasional adalah ciptaan pemerintah dan kekuasaannya ditentukan dengan undang-undang. Hubungan antara pemerintah sub nasional dengan pemerintah adalah hubungan sub-ordinasi”.

Sebagai sebuah konsep, negara kesatuan sering diposisikan secara berlawanan dengan negara federal atau serikat. Sebuah negara dikategorikan sebagai negara federal jika negara-negara bagian dalam negara itu memiliki kekuasaan yang melekat (inherent authorities) dan tidak dapat ditarik oleh pemerintah pusat / federal. Istilah "negara bagian" (sub-division of country atau sub-national) berbeda-beda di setiap negara federal. Istilah ini merujuk pada State di Amerika Serikat, Brazil dan India; Kantone atau Canton di Swiss; Federated Republics di Rusia; Länder di Jerman; Kerajaan Negeri di Malaysia; Province di Argentina, Kanada dan Pakistan; Emirates di UEA; Community di Belgia; Island di Komoro; Region di Ethiopia; dan sebagainya. Dilihat dari susunannya, Budihardjo (1983) mendefinisikan sebagai negara yang tersusun dari gabungan beberapa negara yang berdiri sendiri dengan mengadakan ikatan yang efektif, sehingga terbentuk negara baru. Dengan kata lain, susunan negaranya adalah jamak. Dalam Negara serikat / federasi ini terdapat dua carapembagian kekuasaan antara pemerintah federal dengan negara bagian, yakni: 1) memerinci dan menyebut satu per satu kekuasaan (enumerated power) untuk pemerintah federal, sedang kekuasaan selebihnya (reserved power) dimiliki atau diserahkan kepada negara bagian. Cara ini dimaksudkan untuk memperkuat Negara bagian; dan 2) memerinci kekuasaan untuk negara bagian, dan sisa kekuasaan diserahkan kepada pada pemerintah federal. Dalam hal ini, kekuasaan negara bagian dibatasi, sedangkan kekuasaan pemerintah pusat (federal) diperluas atau diperkuat.

Di negara federal seperti ini, tidak ada tingkatan pemerintahan yang menjadi subordinasi dari tingkatan pemerintahan lainnya, dan tidak ada pula suatu pemerintahan tertentu yang dapat melakukan konsentrasi atau pemencaran kewenangan secara sepihak (unilateral). Federalisme sebagai sebuah prinsip institusional mengidentifikasikan diri 
sebagai antitesa terhadap sentralisasi. Dalam kaitan ini Baldi ${ }^{10}$ menyatakan sebagai berikut :

Federalism denies the existence of just one "center" able to centralize or decentralize power, and it develops, instead, a multi-centered and noncentralized structure of government, where each center is given a guaranteed portion of power which can not be removed by the others. (Federalisme menyangkal keberadaan hanya satu "pusat" yang mampu memusatkan atau mendesentralisasi kekuasaan, dan justru mengembangkan struktur pemerintahan yang multi-terpusat dan tidak terpusat, di mana setiap pusat diberikan bagian kekuasaan yang dijamin yang tidak dapat dihilangkan oleh pemerintah lainnya).

Menarik untuk menyimak pernyataan Lijphart ${ }^{11}$ bahwa federalisme memang sering diikuti dengan desentralisasi, namun federalisme bukan prasyarat untuk desentralisasi, dan sebaliknya. Desentralisasi dapat terjadi pada sistem kenegaraan yang tidak mengenal federalisme, dan sebaliknya, federalisme maupun sistem negara kesatuan dapat berkarakter desentralisasi ataupun sentralisasi. Pernyataan ini menegaskan bahwa bentuk negara tidak memiliki hubungan langsung dengan manajemen pemerintahan secara sentralistis atau desentralistis. Dalam kaitan ini, King ${ }^{12}$ dalam kalimat aslinya menyatakan:

"there is no observed degree of centralization/decentralization which commonly and distinctly marks off federations from so-called unitary states". ("Tidak ada yang diamati tingkat terpusat / desentralisasi yang secara umum dan jelas yang menandai federasi dari apa yang disebut negara kesatuan").

Pernyataan senada diungkapkan Azfar, et.al. ${ }^{13}$, bahwa negara federal tidak selamanya lebih terdesentralisasi. Hanya saja, memang terdapat kecenderungan bahwa di negara-negara federal derajat sentralisasinya lebih rendah dibandingkan di negara kesatuan, meski harus diakui pula bahwa di kedua bentuk negara tersebut tidak bisa

10 Brunetta Baldi, Beyond the Federal-Unitary Dichotomy, Working paper, Institute of Governmental Studies, University of California, Berkeley, 1999, hlm. 4.

${ }^{11}$ Lihat dalam Robertson Work, Op.Cit., hlm.7 ; Brunetta Baldi, Op.Cit., hlm. 12

12 Brunetta Baldi, Op.Cit., hlm. 12

13 Azfar, Omar, Satu Kähkönen, Anthony Lanyi, Patrick Meagher, and Diana Rutherford, Decentralization, Governance and Public Services, The Impact Of Institutional Arrangements: A Review of the Literature, IRIS Center, University of Maryland, College Park. September, 1999, hlm. 8. 
dihindarkan adanya urusan-urusan yang masih dikelola secara sentralistis. Beberapa urusan tertentu bahkan hanya dapat dilakukan secara sentralisasi ${ }^{14}$.

\section{Desentralisasi Simetris dan Asimetris.}

Smith sebagaimana disitir oleh Azfar et.al ${ }^{15}$., mengatakan bahwa sebuah negara kesatuan dapat melakukan devolusi terhadap urusan-urusan yang penting, sehingga akan memunculkan bentuk baru negara yakni semi-federal (quasi federal arrangement). Model ini dalam beberapa hal bersifat seragam (uniform /symmetrical) namun dapat pula tidak seragam (asymmetrical). Contoh dari model quasi-federal arrangement ini adalah Philipina dan Indonesia. Pemerintah Philipina memberi otonomi yang lebih luas kepada Muslim Mindanao dan Cordillera (1989), namun tetap mempertahankan bentuk yang seragam (simetris) untuk wilayah lainnya. Kasus serupa terjadi di Indonesia yang memberikan otonomi khusus (asimetris) kepada Provinsi Aceh dan Provinsi Papua, ${ }^{16}$ namun memberlakukan sistem yang sama (simetris) untuk wilayah lainnya (kecuali Jakarta sebagai Ibukota Negara dan Daerah Istimewa Yogyakarta ${ }^{17}$ ) Kondisi ini sering dikenal dengan istilah asymmetric decentralization ${ }^{18}$.

Mencermati beberapa pandangan diatas, semakin kabur batas-batas antara negara kesatuan dan negara federal, terlebih lagi jika harus dikaitkan dengan derajat desentralisasinya. Berdasarkan khazanah literatur, memang tidak ada bentuk negara

${ }^{14}$ Bandingkan dengan Pasal 10 Ayat (1) UU No.23 Tahun 2014 tentang Pemerintahan Daerah yang merumuskan :

(1) Urusan pemerintahan absolut sebagaimana dimaksud dalam Pasal 9 ayat (2) meliputi: a. politik luar negeri; b.pertahanan; c. keamanan; d. yustisi; e. moneter dan fiskal nasional; dan f. agama.

${ }^{15}$ Azfar, et.al., Op.Cit, hlm.8

${ }^{16}$ Otonomi Khusus bagi Aceh dan Papua masing-masing diatur dalam UU No. 18/2001 tentang Otonomi Khusus Bagi Provinsi Daerah Istimewa Aceh Sebagai Provinsi Nanggroe Aceh Darussalam sebagaimana diganti dengan UU No. 11/2006 tentang Pemerintahan Aceh dan UU No. 21/2001 jo UU No. 35 Tahun 2008 tentang Otonomi Khusus Bagi Provinsi Papua.

${ }^{17}$ Diatur dalam UU No. 29 Tahun 2007 Tentang Pemerintahan Provinsi Daerah Khusus Ibukota Jakarta Sebagai Ibukota NKRI (sebagai pengganti UU No. 34 Tahun 1999 tentang Pemerintahan Provinsi Daerah Khusus Ibukota Negara Republik Indonesia Jakarta (Lembaran Negara RI Tahun 1999 No. 146) dan UU No. 13 Tahun 2012 tentang Keistimewaan DIY.

${ }^{18}$ Istilah lain yang merujuk pada pengertian yang kurang lebih sama adalah asymmetric regionalism atau asymmetric federalism. Contoh dari asymmetric regionalism terjadi di Spanyol yang memberi otonomi kepada pemerintah sub-nasional berdasarkan permintaan (autonomy on demand). Oleh karenanya, setiap pemerintah subnasional bisa memiliki luas kewenangan dan rincian kewenangan yang berbeda-beda. Contoh yang lain terjadi di Inggris Raya, dimana Inggris lebih menerapkan administrative deconcentration, sedangkan Wales memilih desentralisasi, dan prinsip neo-regionalism diterapkan di Skotlandia. Lihat: "Politica Comparata", Center for the Study of Political Change Website, http://www.gips.unisi.it/circap/politica-comparata ; Lihat juga: Jeffery (2009, 289-290). Dalam praktek di berbagai negara, asymmetric decentralization tadi menjelma dalam berbagai variasi. Sebagai contoh, di China juga terdapat bentuk desentralisasi asimetris yg diterjemahkan sebagai kombinasi antara desentralisasi ekonomi kepada daerah dengan desentralisasi politik kepada partai-partai politik (Chien, 2007: 275). 
kesatuan atau negara federal yang murni. Eko Prasojo ${ }^{19}$ menulis bahwa tidak mungkin terdapat suatu negara yang sangat bersifat unitaris (kesatuan) atau sebaliknya sangat bersifat federalis. Elemen hubungan antara pusat dan daerah tidak bersifat monosentris, melainkan polisentris bergerak yang dari satu kontinuum ke kontinuum lainnya, dari kontinuum unitaris ke kontinuum federalis dan sebaliknya. Titik temu keseimbangan antara gerakan sentripetal dan sentrifugal dalam hubungan pusat dan daerah, dapat dikaji dalam berbagai aspek, misalnya saja dalam aspek tingkatan dan kedudukan pemerintah daerah, pembagian kewenangan, aspek intervensi pusat terhadap daerah, aspek keterlibatan daerah di tingkat pusat, aspek pembagian (perimbangan) sumberdaya keuangan, dan aspek penyelesaian konflik yang terjadi antar level pemerintahan.

Mengambil analogi tentang hubungan desentralisasi dan dekonsentrasi, maka korelasi antara konsep negara kesatuan dengan negara federal juga tidak bersifat dikhotomis yang saling berlawanan, melainkan membentuk sebuah hubungan matriks atau kontinuum. Dalam rentang garis continuum tadi, sangat dimungkinkan terjadinya pergeseran pendulum baik yang bersifat sentripetal (memusat atau mengerucut dalam kekuasaan yang lebih tinggi) maupun yang sentrifugal (menyebar atau pemencaran kedalam kekuasaan unit pemerintahan yang lebih kecil). Menurut Prasojo, dalam praktek hubungan antara pusat dan daerah di berbagai negara, pendulum unitarisme dan federalisme saling bergerak ke arah yang berlawanan. Bahkan sejak tahun 1947seorang sarjana hukum Jerman Bodo Denewitz mengatakan bahwa federalisme dan unitarisme adalah dua konsep kembar yang tidak mungkin membicarakan satu tanpa membicarakan yang lainnya.

Ilustrasi menarik dibangun oleh Buchanan ${ }^{20}$ yang menyiratkan bahwa model negara kesatuan dan model federal tidak akan menjadi dua kutub yang berlawanan secara diametral, melainkan cenderung akan bergerak pada satu titik keseimbangan

${ }^{19}$ Eko Prasojo, Konstruksi Ulang Hubungan Pemerintah Pusat dan Pemerintah Daerah di Indonesia : Antara Sentripetalisme dan Sentrifugalisme, Pidato Pengukuhan Guru Besar Tetap dalam Ilmu Administrasi Negara, Jakarta: FISIP-UI, 2008.

${ }^{20}$ Buchanan, James M., Federalism as an Ideal Political Order and an Objective for Constitutional Reform, in Publius, Vol. 25, No. 2 (Spring). Oxford University Press., 1995, hlm. 24 
(equilibrium point) yang disebut competitive federalism. Wagner ${ }^{21}$ memberikan $^{2}$ deskripsi competitive federalism sebagai :

“...an intellectual construction that locates governance within an openly competitive approach to processes of social organization. This construction stands in contrast to that of dual federalism, which envisions different levels of government as possessing sole, monopolistic authority in their assigned areas. Competitive federalism allows for different levels of government to compete to provide services, maximizing the number of people whose preferences are met”. (...konstruksi intelektual yang menempatkan tata kelola dalam pendekatan persaingan terbuka untuk proses organisasi sosial. Konstruksi ini sangat berbeda dengan federalisme ganda, yang memimpikan tingkat pemerintahan yang berbeda sebagai satu-satunya yang memiliki otoritas monopolistik di wilayah yang ditugaskan kepada mereka. Federalisme yang kompetitif memungkinkan berbagai tingkat pemerintahan bersaing untuk menyediakan layanan, memaksimalkan jumlah orang yang preferensi terpenuhi ").

Model Buchanan sendiri dibangun dalam konteks untuk mendorong reformasi konstitusional di suatu negara agar menjadi lebih demokratis namun efektif dan efisien. Jika kondisi saat ini (status quo) diasumsikan sebagai negara kesatuan yang tersentralisasi (yakni pada titik ekstrim kiri), maka reformasi harus mencakup upaya devolusi dari kekuasaan asli (genuine authority) dari pusat kepada unit-unit pemerintahan yang lebih rendah. Sebaliknya, jika kondisi saat ini diasumsikan sebagai sebuah unit politik yang sangat otonom, yang meskipun berdekatan namun memiliki kemungkinan untuk melepaskan diri dari ikatan yang lebih besar (yakni pada titik ekstrim kanan), maka reformasi justru harus berupa sentralisasi kekuasaan / kewenangan, atau transfer kekuasaan asli (genuine authority) dari unit-unit pemerintahan yang lebih kecil kepada pemerintah nasional. Kedua titik tersebut cenderung akan bergerak, sehingga struktur negara yang efektif berada di tengah-tengah atau diantara kedua titik ekstrim tersebut, yaitu pada wilayah yang disebut competitive federalism.

${ }^{21}$ Wagner, Richard,"Chapter 2: Competitive Federalism in Institutional Perspective”, dalam Racheter, Donald P. and Richard Wagner, ed. Federalist Government in Principle and Practice, Kluwer Academic Publisher, 2001, http://www.limitedgovernment.org/books/fe deralist_gov.html 
Salah satu kritik utama terhadap negara kesatuan datang dari Patrick Meagher dan Mancur Olson ${ }^{22}$ yang menyebutkan bahwa negara kesatuan atau rezim yang sentralistis sering mengalami kekurangan sarana (misalnya infrastruktur komunikasi) untuk mengatur wilayah yang luas. Untuk memecahkan masalah ini, disarankan agar dibentuk unit-unit pemerintahan yang lebih kecil. Permasalahan lain dikemukakan Devas ${ }^{23}$ yakni lemahnya kontrol yang dilakukan pusat terhadap unit-unit pemerintahan dibawahnya. Seringkali, kontrol pusat justru menimbulkan masalah yang lebih banyak dari pada yang dapat diselesaikan, misalnya adanya keterlambatan, ongkos/biaya ekstra, atau kemungkinan perilaku yang kurang terpuji.

Kelemahan negara kesatuan secara agak lengkap dipaparkan dalam Politica Comparata (Center for the Study of Political Change, 2008). Kelemahan pertama adalah persoalan "jarak", dimana pemerintahan diatur dari pusat namun dijalankan di level lokal. Model manajemen top down juga juga berpotensi menimbulkan komplikasi. Dalam model ini, penunjukkan pejabat-pejabat tertentu dilakukan oleh pusat disertai dengan rotasi secara rutin untuk menghindari adanya sindrom "going native" (lebih condong memperjuangkan kepentingan lokal), kebutuhan untuk selalu menyesuaikan program pusat dengan budaya lokalisme, serta kemungkinan munculnya tensi antara pusat dan daerah. Sebaliknya, paham federalisme sering dipahami sebagai sumber dari meruncingnya konflik etnik yang memperkuat gerakan separatis. Bentuk negara ini juga berpotensi memperlebar kesenjangan antar wilayah, serta kadangkala kurang efektif dan efisien, khususnya di negara-negara berkembang dengan infrastruktur yang minim ${ }^{24}$. Contoh yang diajukan oleh Work adalah Srilanka, sebuah negeri multi-etnik, multiagama dan multi-bahasa yang sedang dalam proses mengadopsi "Devolution Package" yang komprehensif dalam rangka mereformasi konstitusinya, dan pada akhirnya memilih sistem federal. Banyak yang berpendapat bahwa penerapan bentuk negara federal akan memperburuk gerakan separatis dan anti demokrasi, sekaligus menempatkan negara dalam sebuah resiko besar. Dengan kondisi yang ada saat ini, banyak pihak meyakini bahwa dengan kekuasaan pusat yang kuat maka pembangunan

${ }^{22}$ Azfar et.al.,Op.Cit., hlm. 8

${ }^{23}$ Nick Devas, The Challenges of Decentralization, paper presented at Global Forum on Fighting Corruption, Brasília, June, 2005, hlm. 5, http://bvc.cgu.gov.br/bitstream/123456789/2 037/1/nickdevas-2.pdf.

${ }^{24}$ Robertson Work, Op.Cit., hlm. 8 
dan pertumbuhan ekonomi dapat ditingkatkan. Pada akhirnya, banyak kajian yang menyimpulkan bahwa tidak ada alasan secara ekonomis maupun politis yang cukup meyakinkan untuk membagi Srilanka menjadi 9 (sembilan) negara bagian.

Negara kesatuan (maupun negara federal) bisa terdesentralisasi atau tersentralisasi, namun kecenderungan global adalah pergerakan kearah negara yang desentralistis. Sebagai contoh, Myanmar adalah salah satu contoh ekstrim negara yang dikategorikan sebuah rezim yang sangat sentralistis di Asia. Meskipun kekuasaan negara masih dipegang oleh junta militer, namun tetap saja terdapat hasrat untuk melakukan reformasi dengan memberikan otonomi kepada pemerintahan yang lebih rendah. Desentralisasi di Myanmar ini ditujukan untuk meningkatkan partisipasi publik, akuntabilitas birokrasi, efisiensi administratif, serta respon terhadap kebutuhan masyarakat, disamping tujuantujuan lainnya ${ }^{25}$. Demikian pula di Eropa yang diwakili Inggris dan Perancis. Kedua negara ini pada masa lampau sangat kental nuansa sentralisasinya, malahan lebih tepat disebut sebagai negara yang otoriter. ${ }^{26}$ Dalam era setelah tumbangnya rezim monarkhi baik di Perancis maupun di Inggris, karakteristik Perancis masih sangat sentralistis dan seragam $^{27}$, sementara Inggris Raya juga memiliki reputasi sebagai negara yang paling sentralistis di Eropa ${ }^{28}$.

${ }^{25}$ Fritzen, Scott A. and Patrick W. O. Lim, Problems and Prospects of Decentralization In Developing Countries, LKY School of Public Policy, National University of Singapore, May, 2006, hlm. 1.

${ }^{26}$ Sebagai ilustrasi, pernyataan Raja Louis XIV (5 September 1638 - 1 September 1715) dari Perancis yang sangat terkenal berbunyi: "L'État c'est Moi" (Negara adalah saya). Louis XIV sering dikenal dengan sebutan the Sun King (French: le Roi Soleil). Louis XIV sangat percaya dengan hak suci raja (divine right of kings), sebuah doktrin politik dan agama tentang absolutisme raja. Menurut paham ini, raja mendapatkan kekuasaan langsung dari Tuhan. Atas dasar paham ini, Louis XIV melanjutkan pemerintahan secara sangat sentralistis, dan terus berusaha mematahkan kekuatan di level provinsi yan gsering menjelma dalam bentuk pemberontakan. Saat akan meninggal, Louis XIV mengatakan: Je m'en vais, mais l'État demeurera toujours (I depart, but the State shall always remain).

Lihat: http://en.wikipedia.org/wiki/Divine_right_of_kings , http://en.wikipedia.org/wiki/Louis_XIV_of_France Kondisi Inggris pada abad pertengahan (middle ages) juga sangat serupa. Sebagai contoh, Raja James I (the King of England, 19 June 1566 - 27 March 1625), menulis dua karya berjudul The Trew Law of Free Monarchies dan Basilikon Doron (1597-1598) yang memperkokoh basis ideologi untuk sistem monarkhi. Dalam karya pertama disebutkan tentang teori absolut kerajaan, sehingga raja dapat membuat hukum berdasarkan hak-hak istimewanya. Dalam salah satu bagian, ia menulis sebagai berikut: '[Kings arose] before any estates or ranks of men, before any parliaments were holden, or laws made, and by them was the land distributed, which at first was wholly theirs. And so it follows of necessity that kings were the authors and makers of the laws, and not the laws of the kings". Sedangkan dalam karya kedua lebih banyak dikemukakan prinsip-prinsip yang akan dijadikan pedoman dalam mengatur kerajaan. Lihat: http://en.wikipedia.org/wiki/James_I_of_England.41

${ }^{27}$ Politica Comparata, Ibid.

${ }^{28}$ Jeffery, Charlie, and Daniel Wincott, "Devolution in the United Kingdom: Statehood and Citizenship in Transition", dalam Publius: TheJournal of Federalism, Vol. 36 No. 1. Oxford University Press., 2006, hlm. 3. 
Meskipun demikian, keduanya saat ini justru bisa menjadi contoh dalam keberhasilannya membangun sistem demokrasi melalui pemberian otonomi kepada unit pemerintahan dibawah pemerintah pusat. Kecenderungan terjadinya pergeseran ini dinyatakan secara eksplisit pula oleh Goldsmith dan Newton ${ }^{29}$, sebagai berikut :

"Central government has always been powerful in Britain, which, with France, is one of the most highly centralised, unitary states in the western world, but in the last few years the centre has further consolidated its power by increasing its legal, political, and financial control over local authorities." (Pemerintah pusat selalu berkuasa di Inggris, yang juga dengan Perancis, adalah salah satu negara kesatuan yang paling tersentralisasi di dunia barat, tetapi dalam beberapa tahun terakhir pusat ini semakin mengkonsolidasikan kekuasaannya dengan meningkatkan hukum, politik, dan kontrol keuangan atas otoritas lokal).

Kasus di Belanda tidak jauh berbeda. Hingga akhir 1970-an, sistem pemerintahan Belanda dapat dikatakan sangat sentralistis. Namun mulai era 1980-an, rezim sentralistis ini menunjukkan berbagai kelemahan mendasar, sehingga pada tahun 1980 dan 1982 pemerintah pusat mengeluarkan rencana kebijakan untuk mendesentralisasikan administrasi Negara secara radikal, serta memperkuat posisi pemerintah daerah. Untuk mencapai pemerintahan yang lebih desentralistis tadi, digulirkanlah tiga perubahan kebijakan ${ }^{30}$, yakni:

1) menghapus perundangan level pusat yang mengatur tentang penyelenggaraan fungsi pemerintah daerah;

2) mengganti pola specific grant dengan pola pembiayaan yang tidak menimbulkan ekses intervensi terhadap pemerintah daerah dalam mengambil keputusan; serta

3) penghapusan pedoman administrasi (juklak-juknis) baik yang diterbitkan oleh pemerintah pusat maupun pemerintah tingkat provinsi.

Contoh-contoh dari sistem kenegaraan yang berlaku di berbagai negara di atas kurang mendukung adanya upaya untuk mengkaitkan konsep negara kesatuan dan federal dengan derajat sentralisasi atau desentralisasi. Meskipun tidak ada korelasi yang

${ }^{29}$ Goldsmith, Mike and Ken Newton, "Central-local government relations: The irresistible rise of centralized power", dalam West European Politics, Vol. 6 No. 4., 1983, hlm. 216.

${ }^{30}$ Frederik Fleurke and Rudie Hulst, "A Contingency Approach to Decentralization", dalam Public Organization Review, Vol. 6. Springer Science + Business Media, 2006, hlm. 40 
signifikan antar kedua bentuk negara, namun bentuk negara kesatuan diharapkan lebih komprehensif dalam melakukan reformasi menuju desentralisasi. Sebab, tanggung jawab akhir penyelenggaraan pemerintahan, khususnya dalam hal pembelanjaan anggaran negara, masih berada di tangan pusat. Oleh karenanya, reformasi desentralisasi yang inisiatif berasal dari pusat (top-down) pasti dilakukan dengan mempertimbangkan efisiensi. Pada saat yang sama, dorongan dan tuntutan terhadap desentralisasi yang datang dari bawah (bottom-up), akan berorientasi pada upaya memperbesar demokrasi. Bahkan dalam bentuk negara yang sama, variasi desentralisasinya bisa jadi sangat berlainan. Selain itu, dapat dipahami pula dari paparan diatas bahwa model desentralisasi baik di negara kesatuan maupun negara federal sangatlah bervariasi. Di negara federal, masalah tentang fiskal mungkin sama dengan di negara kesatuan, namun tanggung jawab atas pemecahan masalah sudah sepenuhnya diserahkan kepada pemerintah daerah di berbagai level.

Fakta-fakta yang diungkapkan diatas mengarah pada sebuah pemahaman tidak adanya satupun model desentralisasi dan dekonsentrasi yang seragam antar negara, bahkan antar negara dengan bentuk yang sama. Kondisi yang lebih lazim adalah bahwa sebuah negara menerapkan desentralisasi dan dekonsentrasi secara simultan, dan pada saat yang bersamaan juga menerapkan beberapa variasi dari desentralisasi. Dengan demikian, asymmetric decentralization (desentralisasi yang tidak sama/setara) cenderung lebih banyak dijadikan pilihan terbaik. Pilihan seperti ini secara rasional dapat dimengerti mengingat adanya fakta bahwa dalam sebuah negara (yang berbentuk kesatuan sekalipun), setiap daerah tidak memiliki karakteristik, potensi, latar belakang sejarah, atau setting politik yang sama. Itulah sebabnya, pengaturan yang berbeda menjadi sebuah tuntutan yang wajar.

Konsep asymmetric decentralization sendiri berkembang dari konsep tentang asymmetric federation yang diperkenalkan oleh Charles Tarlton ${ }^{31}$ pada tahun 1965 . Menurut Tillin, terdapat dua jenis asymmetric federation, yakni de facto asymmetry dan de jure asymmetry. Jenis pertama merujuk pada adanya perbedaan antar daerah dalam hal luas wilayah, potensi ekonomi, budaya dan bahasa, atau perbedaan dalam otonomi,

\footnotetext{
${ }^{31}$ Lihat dalam Louise Tillin, "United in Diversity? Asymmetry in Indian Federalism", dalam Publius: TheJournal of
} Federalism, Volume 37 Number 1. Oxford University Press., 2006, hlm. 46-48 
sistem perwakilan atau kewenangan yang timbul karena adanya perbedaan karakteristik tadi. Sedangkan asimetri kedua merupakan produk konstitusi yang didesain secara sadar untuk mencapai tujuan tertentu. Hal ini berhubungan dengan alokasi kewenangan dalam besaran yang berbeda, atau pemberian otonomi dalam wilayah kebijakan tertentu, kepada daerah tertentu saja.

Kemungkinan terjadinya asymmetric decentralization ini menurut Syarif Hidayat lebih besar di negara kesatuan, sementara di negara federal cenderung menerapkan pola umum berupa otonomi penuh. Sedangkan dalam negara kesatuan, variasi otonomi yang dapat diberikan kepada daerah meliputi tiga bentuk kemungkinan, yakni otonomi luas, otonomi terbatas, serta otonomi khusus. Ketika beberapa bentuk otonomi dijalankan secara bersamaan seperti inilah, maka asymmetric decentralization telah terjadi.

Tabel : Perbandingan Desentralisasi dan Otonomi di Negara Federal dan Negara Kesatuan

\begin{tabular}{|l|l|l|}
\hline BENTUK NEGARA & DESENTRALISASI & $\begin{array}{l}\text { OTONOI } \\
\text { DAERAH }\end{array}$ \\
\hline Federal & $\begin{array}{l}\text { Separation of powers } \\
\text { (pemi-sahan kekuasaan/ } \\
\text { kewenang-an) }\end{array}$ & Otonomi penuh \\
\hline Kesatuan & $\begin{array}{l}\text { Division / distribution of } \\
\text { powers (pembagian } \\
\text { kekuasa-an / } \\
\text { kewenangan). }\end{array}$ & $\begin{array}{l}\text { Otonomi luas } \\
\text { Otonomi terbatas } \\
\text { Otonomi khusus }\end{array}$ \\
\hline
\end{tabular}

Sumber: Syarif Hidayat (bahan presentasi tanpa tahun, tanpa judul)

Berdasarkan deskripsi diatas maka dapat disimpulkan bahwa konsep otonomi pada negara kesatuan dan negara federal tidak dapat dibedakan secara mendasar. Kesimpulan seperti ini misalnya dikatakan oleh Work ${ }^{32} \mathrm{sbb}:$ "There is no broad-based generalization that can be made about the correlation of federal/unitary states and decentralization". ("Tidak ada generalisasi berbasis luas yang dapat dibuat tentang korelasi negara federal / kesatuan dan desentralisasi").

Fakta menunjukkan bahwa negara federal dapat bersifat sangat sentralistis, seperti Malaysia, dan sebaliknya negara kesatuan seperti China justru memiliki derajat desentralisasi yang relatif tinggi. Meskipun demikian, ada sebuah trend yang terjadi di

${ }^{32}$ Robertson Work, Op.Cit., hlm. 11 
kedua bentuk negara, yakni pergerakan bandul sistem politik yang lebih mengarah pada penguatan desentralisasi serta keseimbangan wewenang dan tanggungjawab dalam penyelenggaraan negara dan pemerintahan. Hal ini berimplikasi pada tuntutan untuk mengurangi campur tangan atau wewenang pusat, yang selama ini dikemas dalam kerangka dekonsentrasi. Pergerakan bandul desentralisasi itu sendiri memiliki kecepatan dan variasi yang berbeda di masing-masing negara, yang mendorong terjadinya konstruksi desentralisasi secara asimetris.

\section{Simpulan}

Berdasarkan uraian di atas, maka yang menjadi pokok simpulan dalam tulisan ini sebagai berikut : Pertama, Desentralisasi asimetris bukanlah merupakan penyimpangan dari ide dasar desentralisasi, tetapi justru dapat memperkuat tujuan desentralisasi yakni untuk menciptakan efektivitas dan efisiensi penyelenggaraan negara, sekaligus memperkokoh struktur demokrasi di tingkat lokal. Pembangunan demokrasi lokal memiliki probabilitas untuk lebih diperkuat dengan cara mengakui dan mengakomodasikan setiap perbedaan karakteristik, potensi, kebutuhan, dan latar belakang sejarah masing-masing daerah kedalam sistem kebijakan nasional;

Kedua, Mengingat bahwa setiap daerah / wilayah dalam sebuah negara memiliki anatomi politik, sosial, maupun kultural yang beragam, maka desain desentralisasi yang berbeda (asimetris) menjadi alternatif yang strategis untuk menghindari terjadinya kekecewaan daerah terhadap pemerintah nasional. Itulah sebabnya, baik di negara kesatuan maupun di negara federal pada masa modern sekarang ini, desentralisasi cenderung tidak sekedar dijadikan sebagai strategi politik melalui transfer wewenang/kekuasaan, atau strategi ekonomi melalui perimbangan keuangan dan fiskal, namun juga menjadi strategi kultural untuk merealisasikan prinsip diversity in unity atau unity in diversity. 3). Dimensi terpenting dari variasi/format desentralisasi adalah mencapai esensi desentralisasi, yakni terwujudnya keseimbangan peran dan tanggungjawab antara pusat dan daerah. Keseimbangan baru ini dapat terwujud dengan kemungkinan pusat semakin mengurangi tingkat intervensinya serta memperluas otonomi kepada pemerintah daerah.

Membangun sistem demokrasi melalui pemberian otonomi kepada unit pemerintahan di bawah pemerintah pusat, meskipun tidak ada korelasi yang signifikan 
antar kedua bentuk negara, namun bentuk negara kesatuan diharapkan lebih komprehensif dalam melakukan reformasi menuju desentralisasi. Sebab, tanggung jawab akhir penyelenggaraan pemerintahan, khususnya dalam hal pembelanjaan anggaran negara, masih berada di tangan pusat. Reformasi desentralisasi yang inisiatif berasal dari pusat (top-down) pasti dilakukan dengan mempertimbangkan efisiensi. Pada saat yang sama, dorongan dan tuntutan terhadap desentralisasi yang datang dari bawah (bottom-up), akan berorientasi pada upaya memperbesar demokrasi.

\section{E. Daftar Pustaka}

Abu Daud Busroh. 2001. Ilmu Negara. Jakarta : Bumi Aksara.

Azfar, Omar, Satu Kähkönen, Anthony Lanyi, Patrick Meagher, dan Diana Rutherford. 1999. Decentralization, Governance and Public Services, The Impact of Institutional Arrangements: A Review of the Literature. College Park : IRIS Center University of Maryland.

Baldi, Brunetta. 1999. Beyond the Federal-Unitary Dichotomy, Working paper, Institute of Governmental Studies. Berkeley : University of California.

Buchanan, James M. 1995. Federalism as an Ideal Political Order and an Objective for Constitutional Reform, in Publius, Vol. 25, No. 2 (Spring). Oxford University Press., Oxford.

Devas, Nick. 2005. The Challenges of Decentralization, paper presented at Global Forum on Fighting Corruption, Brasília, http://bvc.cgu.gov.br/bitstream/123456789/2 037/1/nickdevas-2.pdf.

Eko Prasojo. 2008. Konstruksi Ulang Hubungan Pemerintah Pusat dan Pemerintah Daerah di Indonesia : Antara Sentripetalisme dan Sentrifugalisme, Pidato Pengukuhan Guru Besar Tetap dalam Ilmu Administrasi Negara. Jakarta : FISIPUI.

Elazar, Daniel J. 1997. "Contrasting Unitary and Federal Systems”, dalam International Political Science Review / Revue internationale de science politique, Vol. 18, No. 3, Sage Publications.

Fleurke, Frederik and Rudie Hulst. 2006. A Contingency Approach to Decentralization, dalam Public Organization Review, Vol. 6. Springer Science + Business Media.

Fritzen, Scott A. and Patrick W. O. Lim. 2006. Problems and Prospects of Decentralization In Developing Countries. Singapore : LKY School of Public Policy, National University of Singapore.

Goldsmith, Mike and Ken Newton. 1983. "Central-local government relations: The irresistible rise of centralized power”, dalam West European Politics, Vol. 6 No. 4.

Isjwara, F. 1980. Pengantar Ilmu Politik. Bina Cipta : Bandung.

Jeffery, Charlie, and Daniel Wincott. 2006. "Devolution in the United Kingdom: Statehood and Citizenship in Transition", dalam Publius: TheJournal of Federalism, Vol. 36 No. 1. Oxford University Press., Oxford.

Martin H. Hutabarat (eds). 1996. Hukum dan Politik Indonesia : Tinjauan Analitis Dekrit Presiden Dan Otonomi Daerah. Jakarta : Pustaka Sinar Harapan 
Miriam Budiharjo. 2000. Dasar-dasar Ilmu Politik. Gramedia : Jakarta.

Tillin, Louise. 2006. "United in Diversity? Asymmetry in Indian Federalism”, dalam Publius: The Journal of Federalism, Volume 37 Number 1. Oxford University Press., Oxford.

Wagner, Richard. 2001. Chapter 2: Competitive Federalism in Institutional Perspective, dalam Racheter, Donald P. and Richard Wagner, ed. Federalist Government in Principle and Practice. Kluwer Academic Publisher, http://www.limitedgovernment.org/books/fe deralist_gov.html

Work, Robertson. 2002. Overview of Decentralization Worldwide: A Stepping Stone to Improved Governance and Human Development. UNDP : 2nd International Conference on Decentralization Federalism: The Future of Decentralizing States ?, New York. 